\title{
Utilização de plataforma gênica no prognóstico do câncer de mama
}

\section{Use of a gene plataform in breast cancer prognosis}

Paula Gabriela Casa Cesar ${ }^{1}$, Fernando Luiz Affonso Fonseca ${ }^{1,2}$, Flávia de Sousa Gehrke², Beatriz da Costa Aguiar Alves², Renata Kelly Kuniyoshi², Auro Del Giglio²

\section{RESUMO}

O câncer de mama é o principal tipo de câncer que acomete as mulheres no mundo. Muitos são os fatores que estão associados ao aparecimento e desenvolvimento desse tipo de tumor. Há grande variabilidade interindividual tanto na idade da mulher no momento do diagnóstico de câncer de mama quanto na expressão fenotípica existente nesse mesmo momento, o que torna o diagnóstico desafiante para qualquer pesquisador. $\mathrm{Na}$ última década, houve melhor entendimento sobre os mecanismos moleculares envolvidos na progressão do câncer de mama e sobre o papel central das alterações moleculares na detecção precoce do tumor. O desafio agora é aprender a usar as características moleculares individuais do tumor de cada paciente e melhorar as formas atuais de detecção e de tratamento, visando à prevenção do aparecimento e ao diagnóstico precoce do tumor. Atualmente, dois são os métodos já amplamente utilizados nos Estados Unidos para caracterizar molecularmente os tumores mamários: MammaPrint e OncotypeDX. Este trabalho teve por objetivo discutir esses dois métodos prognósticos do câncer de mama, visando estabelecer diferenças entre eles e suas principais aplicações.

Palavras-chave: neoplasias da mama; estudos epidemiológicos; genética; diagnóstico precoce.

\begin{abstract}
Breast cancer is the leading cancer affecting women worldwide. There are many factors associated with the emergence and development of this tumor type. There is large interindividual variability in both woman's age at breast cancer diagnosis and the phenotypic expression existing at that moment, which makes the diagnosis challenging for any researcher. In the last decade, there was a better understanding of the molecular mechanisms involved in the progression of breast cancer and the central role of molecular changes in early detection of tumor. The challenge now is to learn how to use the individual tumor molecular characteristics of each patient and improve the current forms of detection and treatment, aiming at preventing the onset and the early diagnosis of the tumor. Currently, two methods are already widely used in United States of America to molecularly characterize breast tumors: MammaPrint and OncotypeDX. This paper aimed to discuss these two methods for breast cancer prognosis, in order to establish differences between them and their main application.
\end{abstract}

Keywords: breast neoplasms; epidemiologic studies; genetics; early diagnosis. 


\section{INTRODUCุÃO}

\section{Epidemiologia do câncer de mama}

Aproximadamente, 1,2 milhões de novos casos de câncer de mama são diagnosticados todos os anos no mundo, sendo este o segundo tipo de câncer mais comum entre as mulheres ${ }^{1}$. O câncer de mama é uma doença epidemiologicamente heterogênea, com variações entre as diversas regiões geográficas, apresentando diferentes incidências entre mulheres de diferentes etnias. Os maiores níveis de incidência desse tipo de câncer são encontrados na Grã-Bretanha, Nova Zelândia, Holanda e Uruguai ${ }^{2}$.

No Brasil, o câncer de mama é o tipo de tumor não cutâneo mais frequente em mulheres, representando cerca de $15 \%$ das mortes por câncer. Apesar dessa alta incidência, o câncer de mama tem cura na maioria das mulheres diagnosticadas precocemente ${ }^{1,3}$. Estima-se que aproximadamente $10 \%$ da população feminina dos países ocidentais desenvolverão o câncer de mama em alguma época da vida, sendo a maioria dos casos entre mulheres de 45 e 50 anos $^{3}$, embora se perceba cada vez mais o aumento de casos em mulheres mais jovens.

Cerca de $90 \%$ dos cânceres de mama em todo o mundo são cânceres esporádicos, sem associação com o fator hereditário. O risco de desenvolvimento desse tipo de câncer está fortemente relacionado à produção de esteroides sexuais. Um exemplo disso é o uso indiscriminado da terapia de reposição hormonal, utilizado geralmente em mulheres após a menopausa, que pode levar a aumento nos casos de câncer de mama, como mostra um estudo feito pelo Instituto Nacional do Câncer nos Estados Unidos, realizado em $2003^{4}$

Fatores ambientais, estilo de vida e alimentação interferem muito na gênese do câncer de mama ${ }^{3}$. Outros fatores de risco para o desenvolvimento de câncer de mama estão: idade avançada, fatores reprodutivos, status socioeconômico, urbanização das cidades, histórico familiar de câncer, doenças fibrocísticas na mama, obesidade, radiação ionizante, uso de contraceptivo oral, dieta, álcool, cigarro, lactação, abortos e atividades físicas.

Dados sobre a influência da dieta no risco de desenvolvimento de câncer de mama foram obtidos pelo Iowa Women's Health Study e pelo Nurses Health Study. Foi demonstrado que mulheres que perdem $5 \%$ ou mais do seu peso antes e após a menopausa apresentam uma redução do risco de desenvolver câncer de mama na pós-menopausa na ordem de 40 e $25 \%{ }^{4}$ e que mulheres que perdem pelo menos $10 \mathrm{~kg}$ após a menopausa têm uma redução de risco de câncer de mama na ordem de $56 \%{ }^{5}$.

Estudos indicam que "quanto maior a vida reprodutiva, maior o risco de desenvolver câncer de mama”, o que significa dizer que menarca precoce e menopausa tardia aumentam as chances de desenvolver câncer de mama devido ao ciclo hormonal que ocorre nesse período. Além disso, a primeira gestação em idade mais avançada aumenta o risco de ter câncer de mama ${ }^{6,7}$.

A associação entre câncer de mama e ingestão de proteína animal foi fortalecida por meio de estudos realizados em 30 países.
Há uma associação positiva entre ingestão gordurosa e neoplasia maligna de mama. O sul do Brasil destaca-se pelo mais alto consumo de carne e coincidentemente é a capital que apresenta mais altos índices de câncer de mama ${ }^{6}$.

A atual condição da mulher brasileira aproxima-se da encontrada em mulheres de países desenvolvidos, tendo um índice de fecundidade menor de três filhos. Essa mudança no perfil da população brasileira, no que diz respeito aos estilos de vida e ao comportamento reprodutivo, pode ser traduzida em aumento no número de casos de câncer de mama. O mesmo pode ser observado em outros países em desenvolvimento ${ }^{4}$.

Além desses fatores de risco associados com o aumento da susceptibilidade ao câncer de mama, o histórico familiar é o fator mais importante. Embora apenas de 5 a 10\% dos cânceres de mama sejam hereditários ${ }^{8}$, a probabilidade de uma mulher que tenha um parente de primeiro e/ou segundo grau que já tenha apresentado câncer de mama desenvolver o tumor aumenta muito. Essa variável é uma das que apresenta maior razão de riscos para o desenvolvimento da doença, que geralmente acomete mulheres relativamente mais jovens do que o câncer de mama esporádico ${ }^{7}$. Existe um risco cinco vezes maior de desenvolvimento do câncer entre mulheres que possuem parentes próximos, como irmã e/ou mãe, que já tiveram câncer de mama, se comparado com mulheres sem antecedentes familiares de neoplasia mamária ${ }^{7}$.

Cerca de 30\% das mulheres que desenvolverem câncer de mama apresentam um componente genético de predisposição à doença, principalmente aquelas mulheres que apresentam carcinoma bilateral associado a outras neoplasias, como o câncer de colón de ovário9.

O risco de desenvolvimento do câncer de mama entre mulheres de diferentes grupos étnicos varia. Os índices de incidência e mortalidade por câncer de mama em mulheres hispânicas é mais baixo quando comparado a mulheres negras. No entanto, ainda é a segunda causa de mortalidade por câncer em mulheres nos países da América Latina, ficando atrás somente do câncer cervical. Outros estudos mostraram que as hispânicas têm a menor taxa de câncer de mama familiar se comparados a brancos e negros. Isso pode ser devido à dieta típica dos hispânicos, composta principalmente por fibras, que pode reduzir os níveis de estrógenos circulantes ${ }^{10}$.

Entre as mulheres africanas e americanas, o câncer de mama é o principal tipo de câncer. A média anual de incidência de câncer de mama é menor nas mulheres negras (92.8 per 100.000) quando comparado a mulheres brancas (112.2 per 100.000). Entre as jovens, as negras apresentam maior taxa de desenvolvimento de câncer e entre as mais velhas, sãs as brancas que têm maior risco. O motivo para isso ocorrer ainda é desconhecido ${ }^{10}$.

Embora existam diferenças de etiologia do câncer de mama em populações diferentes, a distribuição desse câncer é similar de acordo com a idade, mostrando um relativo aumento de incidência entre 25 e 45 anos, seguido de um decréscimo na taxa de velocidade de desenvolvimento do tumor após 45 anos. Esse 
dado mostra a influência dos hormônios no desenvolvimento do câncer de mama. Contudo, o câncer de mama é principalmente uma doença pós-menopausa, afetando cerca de $4 \%$ das mulheres com menos de 35 anos e 7\% das mulheres com menos de 40 anos. A maioria dos casos ainda é diagnosticada entre mulheres de 45 a 55 anos $^{7}$, embora seja cada vez mais comum o aparecimento do tumor em mulheres mais novas.

\section{Avanços no diagnóstico}

A mamografia é um exame de diagnóstico de imagem cuja finalidade é estudar o tecido mamário. É capaz de detectar nódulos nas mamas que não sejam palpáveis.

$\mathrm{O}$ acesso à mamografia permite a prévia detecção de tumores de mama em estágios iniciais da doença, diminuindo a idade média de mulheres com diagnóstico positivo de câncer de mama nas diferentes gerações. Isso explica por que na análise de gerações subsequentes de famílias com diagnóstico de câncer de mama há um declínio de oito a dez anos da idade média das mulheres diagnosticadas com câncer de mama ${ }^{7}$.

Essa técnica de diagnóstico tem sido a principal forma de screening de câncer de mama por muitas décadas, levando à diminuição da mortalidade por esse câncer em mulheres de 50 a 59 anos. No entanto, essa técnica não reduz a mortalidade em mulheres mais jovens em razão de baixas taxa de incidência de câncer de mama nessa idade, do aumento da densidade do tumor de mama e do rápido crescimento do tumor ${ }^{8}$. A mamografia tem uma sensibilidade de apenas 16 a $40 \%$.

A técnica de Ressonância Magnética de Imagem (RMI) é outro método de diagnóstico altamente sensível para mulheres com alto risco de desenvolvimento do tumor de mama, apresentando uma taxa de sensibilidade de 77 a 100\%. Além disso, é capaz de identificar tumores menores do que a mamografia conseguiria detectar, sem o risco de exposição à radiação ${ }^{8}$.

As novas metodologias de detecção da doença em muito têm contribuído com o diagnóstico precoce, o que pode ajudar a ter um melhor prognóstico e maiores chances de cura.

Nos estágios precoces do câncer de mama, a cirurgia é o principal tratamento e, com a radioterapia, pode controlar a doença locorregionalmente na maior parte dos casos. No entanto, cerca de $30 \%$ das pacientes morrem em decorrência da doença disseminada. É por isso que para erradicar as micrometástases e prolongar o tempo livre de recaída têm sido desenvolvidos tratamentos adjuvantes, como a hormonoterapia ou quimioterapia ${ }^{11}$. É necessário que se faça uma avaliação das pacientes candidatas aos tratamentos adjuvantes. Para isso, se aplicam parâmetros clínico-patológicos, como idade, tamanho tumoral, comprometimento dos linfonodos axilares, tipo e grau histológico do tumor, e receptores hormonais.

Os avanços das bases genéticas do câncer permitem identificar alguns dos genes responsáveis pela patogênese do câncer de mama. Entre as estratégias para se identificar novos marcadores do câncer de mama, estão os Métodos de Alto Rendimento
(High-throughput Analysis), que se caracterizam por ser uma análise de múltiplos marcadores genéticos em um só experimento (de 100 a 25.000 análises simultâneas) ${ }^{11}$.

$\mathrm{O}$ método mais usual para identificação de marcadores moleculares é o microarray de cDNA, que se baseia na hibridação de moléculas de RNA do tecido tumoral contra sequências do genoma humano impressas num suporte sólido. Para reconhecer quais os genes estão expressos no tecido tumoral, o RNA do tumor é convertido em cDNA e marcado com uma molécula fluorescente que emite coloração vermelha em 650-750 nm (Texas red). Já as sequências impressas no suporte sólido são marcadas com FITC, que emite fluorescência de coloração verde. Se houver hibridação entre o cDNA do tumor e as sequências do genoma humano, predominará o sinal vermelho do Texas red. O sinal de FICT aparece se não houver hibridação, ou seja, o gene não está expresso naquele tumor ${ }^{11}$. Essa técnica já vem sendo usada para identificar perfis de expressão gênica para classificação de leucemias, câncer de pulmão e agora para identificar marcadores de classificação e prognóstico de câncer de mama.

\section{Genética do câncer de mama}

O câncer é uma doença complexa causada pela acumulação progressiva de múltiplas mutações gênicas combinadas com desregulação epigenética de genes críticos e das vias das proteínas relacionadas com o crescimento celular ${ }^{8}$.

Está claro que os cânceres humanos são causados por alterações de genes envolvidos na regulação do crescimento (oncogenes, genes supressores de tumor, genes responsáveis pelo reparo do ciclo celular). Em muitos casos, o desenvolvimento do tumor se deve a alterações de vários desses genes. Por esse motivo, diz-se que a etiopatogenia do câncer de mama é multifatorial, o que dificulta a seleção de um grupo de mulheres com maior risco de desenvolver a doença ${ }^{3}$.

A maioria dos cânceres de mama (80\%) é esporádica por causa das mutações adquiridas em genes ao longo da vida, e a idade de aparecimento do tumor se dá entre os 65 e 80 anos. Aproximadamente, 10 a 15\% dos cânceres de mama são familiares, nos quais mais indivíduos são afetados pelo câncer do que o esperado, e a idade de início do câncer é variável, de 55 a 70 anos. Já os cânceres mamários hereditários representam de 5 a 10\% e têm início precoce, antes dos 50 anos. Trata-se de um padrão de herança autossômico dominante no qual os sujeitos afetados em cada geração são do mesmo lado da família ${ }^{12}$.

Sabe-se que as células mamárias proliferam-se extensivamente mediante a regulação de hormônios sistêmicos e de interações epiteliais, se diferenciando durante a gravidez e a lactação. Por isso, é provável que o repertório celular da glândula mamária seja gerado por componentes de células-tronco. Dessa maneira, os alvos da transformação durante a carcinogênese mamária podem ser tanto as células-tronco quanto as células progenitoras, o que vai resultar na heterogeneidade de tipos de cânceres de mama entre diferentes pacientes ${ }^{8}$. 
Existem ao menos três grandes subtipos de câncer de mama invasivo (CMI) do ponto de vista genético com relevância prognóstica e terapêutica. O CMI do tipo Luminal se caracteriza por uma alta expressão de receptores estrogênicos (RE), o que proporciona uma boa resposta à hormonoterapia, se associando a um melhor prognóstico. O CMI HER-2 positivo apresenta o genótipo RE negativo e se associa com a sobre-expressão de genes relacionados com uma maior agressividade biológica, conferindo um prognóstico pior. Esse subtipo apresenta uma resistência maior a determinados quimioterápicos (ciclofosfamida, metotrexato e fluoruracilo), mas responde bem ao anticorpo monoclonal anti-HER-2 (trastuzumab). Já o CMI Basal like possui o fenótipo triplo negativo, pois apresenta negatividade para os RE, receptores de progesterona $(R P)$ e receptores HER-2. Apresentam uma superexpressão do fator de crescimento epidérmico (EGFR), possuindo pleomorfismo e alto grau mitótico. Portanto, trata-se de um subtipo de prognóstico ruim, embora responda à quimioterapia ${ }^{13}$.

\section{Genes mais expressos}

Numerosos fatores estão relacionados com a carcinogênese mamária. A maioria corresponde a alterações genéticas, como as mutações nos genes BRCA1 e BRCA2 em casos de câncer familiar, e a ativação de oncogenes ou inativação de genes supressores de tumor em cânceres esporádicos ${ }^{14}$.

Entre todas as possíveis alterações genéticas, as que mais frequentemente vêm sido reportadas em artigos científicos são a superexpressão do oncogene HER-2/neu e do gene supressor de tumor P53.

Sabe-se que o HER-2/neu codifica um fator de crescimento do tipo receptor que é inserido na membrana da célula. Essa proteína é detectada superexpressa em 30\% dos casos de câncer de mama. A superexpressão do gene HER-2 pode estar associada a um comportamento biológico agressivo do câncer e poucas chances de sobrevida ${ }^{2}$. Isso torna o HER-2 um possível candidato a biomarcador preditivo do câncer de mama ${ }^{15,16}$.

O gene P53 codifica uma proteína nuclear encontrada em baixos níveis nas células. Essa proteína age restringindo a proliferação celular inapropriada, funcionando como inibidor do crescimento. A proteína P53 se liga a regiões específicas do DNA, onde regula a expressão de outros genes. Uma deleção no braço curto do cromossomo 17 leva à perda do $P 53$ e está associada a um fenótipo maligno in vitro. Cerca de 15 a $60 \%$ dos tumores de mama apresentam a superexpressão do $P 53$, detectada por imunohistoquímica ${ }^{2}$. O P53 está mais envolvido no desenvolvimento esporádico do câncer de mama.

No caso de famílias com alto risco de desenvolvimento de câncer de mama, os mais importantes genes supressores de tumor associados são $B R C A 1$ e $B R C A 2$, bons preditores de desenvolvimento de câncer de mama e de ovário ${ }^{8,12}$. Esses genes são genes supressores de tumores que participam na regulação do ciclo celular e reparação do DNA. Aproximadamente 30\% dos cânceres hereditários de mama e do câncer de ovário se devem a mutações nesses genes. Somente outros 5\% ocorrem por mutações em outros genes ${ }^{12}$. Mulheres que carregam mutações no BRCA1 têm uma probabilidade de cerca de $80 \%$ de desenvolvimento do tumor de mama e 40 a $60 \%$ de chance de desenvolver câncer de ovário, fazendo com que essa mutação seja a mais forte preditiva mutação de câncer de mama ${ }^{9,8}$. Além disso, após os 70 anos, elas ainda têm maior probabilidade de desenvolver um segundo carcinoma mamário. Já mulheres que carregam mutações no gene BRCA2 têm uma probabilidade de $85 \%$ de desenvolvimento do câncer de mama ${ }^{9}$.

Essas mutações no gene $B R C A 1$, no entanto, são raras na população em geral, e o histórico familiar de câncer de mama ou o diagnóstico em mulheres jovens é a melhor forma de identificar portadores da mutação ${ }^{12}$. Entre as mulheres que têm dois ou mais parentes com câncer de mama e/ou de ovário, cerca de uma a cada duas apresenta uma mutação no gene BRCA1 ou $B R C A 2$, e entre mulheres que têm ao menos um parente com diagnóstico de câncer de mama, cerca de 1 a cada 18 apresenta uma mutação detectável ${ }^{8}$.

O BRCA1 e o BRCA2 são genes supressores de tumor localizados nos cromossomos 7 e 13, respectivamente. Mais de $600 \mathrm{mu}$ tações do BRCA1 e 450 mutações do BRCA2 já foram descritas segundo o Breast Cancer Information Core database.

Por se tratar de uma herança autossômica dominante, mutações nos genes BRCA são transmitidas verticalmente, a enfermidade se apresenta em cada geração e o portador da mutação tem $50 \%$ de risco de transmitir a mutação a seus filhos. No entanto, o fato de possuir uma mutação no gene $B R C A 1$ ou $B R C A 2$ não significa que a pessoa irá desenvolver o câncer de mama e/ou ovário, mas sim que a pessoa possui um alto risco, $85 \%$ de probabilidade, de desenvolver o câncer de mama ao longo da vida. Logo, o que se herda é a predisposição a ter esse tipo de câncer.

O gene receptor de progesterona $(R P)$ faz parte da família dos receptores esteroides derivados do ácido retinoico. $\mathrm{O} R P$ é importante regulador do crescimento da glândula mamária e do aparelho reprodutor feminino e encontra-se envolvido na gênese de tumores malignos. Esse receptor $R P$ apresenta duas isoformas. A isoforma A é a proteína envolvida com o polimorfismo genético funcional (PROGINS), que leva a um decréscimo de sua estabilidade, fazendo com que a isoforma A, que antes tinha a capacidade de inibir o gene de ativação dos receptores estrogênicos, agora perca essa capacidade e cause inadequado controle sobre esses receptores. Isso acaba expondo a glândula mamária a maior exposição estrogênica. O polimorfismo da isoforma A ainda estimula uma maior expressão da isoforma $\mathrm{B}$, que é responsável pela ativação dos receptores estrogênicos, contribuindo para aumento da ação oncogênica do $R P$. Essa presença do polimorfismo genético funcional no gene $R P$ foi relacionada com o risco significante de câncer de mama ${ }^{3}$. A expressão desse gene é fortemente dependente de estrógeno. 
O gene, entretanto, não está expresso ou é raramente expresso em tumores receptores de estrogênio-negativo ${ }^{16}$.

O gene $M L H 1$ é um dos genes mais importantes relacionados com o reparo do DNA, uma vez que erros de replicação são responsáveis por um emergente grupo de tumores. O gene CDKN2A é um gene supressor de tumor relacionado com o controle do ciclo celular. Esse gene encontra-se inativado em uma série de tumores, como melanomas, tumores de pâncreas e de estômago. O gene FHIT corresponde a um gene supressor de tumor que se inativa frequentemente em vários tipos de cânceres. O gene $\mathrm{CDH} 1$ transcreve uma molécula de adesão fortemente relacionada com o desenvolvimento do câncer, especialmente em decorrência de aspectos relacionados com a invasão e a metásta$\mathrm{se}^{14}$. O gene $A P C$ regula o ciclo celular e, quando mutado, leva à ativação da transcrição de genes de proliferação celular.

Todos esses genes podem sofrer metilação, uma alteração epigenética que pode levar ao aparecimento do câncer. Trata-se de eventos que ocorrem no DNA e modificam o gene, porém sem alterar os nucleotídeos, ou seja, não alteram a sequência do DNA. Essas alterações são importantes, pois podem explicar a participação dos eventos ambientais na tumorigênese. A metilação dos genes ocorre naturalmente e está relacionada com a regulação da transcrição dos genes no período embrionário e até na inativação dos cromossomos X. A hipermetilação em áreas ricas em guanina e citosina no DNA inibe a transcrição por causa da mudança estrutural da cromatina causada pelos grupamentos metila adicionados, o que torna o gene inacessível aos fatores de transcrição. A metilação nos genes supressores de tumor, como o CDKN2A e FHIT, por exemplo, pode levar a um aparecimento do câncer. Metilação na região promotora do gene $A P C$ também podem levar à sua inativação.

Estudos mostraram que múltiplos genes estão metilados durante o processo de carcinogênese mamária e encontraram metilação frequente $(>40 \%)$ para os genes CDKN2A, FHIT, $A P C$ e $C D H 1^{14}$.

O gene KI67 codifica uma proteína nuclear não histona, um biomarcador reprodutível e conveniente do processo de proliferação celular, importante para o desenvolvimento do câncer. A presença de grandes quantidades dessa proteína foi relacionada a uma boa resposta à quimioterapia em casos de câncer de mama num estágio recente ou em estágio avançado localizado ${ }^{16}$.

\section{Métodos de diagnóstico que utilizam esses genes}

Os recentes avanços na tecnologia de DNA microarray e de outros métodos de análise da expressão de genes em larga escala permitiram seu uso na caracterização biológica e no planejamento terapêutico de tumores de mama ${ }^{8}$.

A medicina personalizada leva a um aumento na escala do uso de biomarcadores para garantir que as pacientes com câncer de mama recebam um tratamento adequado. A última década presenciou o surgimento de inúmeros perfis de expressão multigênica que objetivam superar os fatores tradicionais de previsão e prognóstico dos diversos tipos de cânceres.

Um melhor entendimento da doença, a aplicação de biomarcadores tradicionais e a identificação de novos marcadores vêm proporcionando cada vez mais uma visão melhor de quem deveria receber uma terapia contra o câncer, assim como a terapia mais indicada ${ }^{16}$. Entre os marcadores tradicionais, estão os genes: receptor de estrógeno (RE), RP, HER2 e KI67.

As novas tecnologias de alto rendimento da genômica levaram ao aumento da taxa de descoberta de novos potenciais marcadores e facilitaram o desenvolvimento de perfis de expressão gênica, ou "assinaturas" compostas de dois até milhares de genes cujo sentido seja providenciar informações preditivas e até o prognóstico de tumores ${ }^{15}$.

Os ensaios de Oncontype DX e MammaPrint ainda estão passando por estudos clínicos prospectivos para definição de suas reais utilidades.

\section{MammaPrint}

O MammaPrint é um teste que determina quão agressivo é um tumor de mama. É capaz de indicar com precisão o estágio do tumor mamário, para que se escolha o melhor tratamento para o paciente, já que 50\% das mulheres são tratadas com quimioterapia desnecessariamente.

Trata-se de uma assinatura de 70 genes, também testados numa triagem clínica chamada MINDACT, desenvolvida por meio de um estudo dos tumores de mulheres com doença linfonodo-negativa ${ }^{16,8}$. A análise dos 70 genes permite predizer, com boa precisão, como o câncer vai progredir no futuro, além de predizer o risco de metástase.

O MammaPrint é realizado em tecido fresco de tumor, que é imediatamente colocado em um preservante de mRNA após a operação e retirada deste. Esse tecido fresco é mandado para o laboratório clínico da Agendia, localizado na Holanda, onde é feito um teste histológico de coloração para verificar que o tecido de fato possui um tumor. Esse teste de coloração identifica o tumor se seu nível for pelo menos $30 \%$.

O teste de câncer de mama MammaPrint é realizado usando a tecnologia de chip microarray. Trata-se de uma pequena superfície sólida que é dividida em milhares de minúsculas grades. Cada grade contém um DNA e cada DNA, um código diferente que corresponde a um gene específico, que no caso do MammaPrint trata-se de um gene de tumor mamário. Somente o RNA desse gene particular pode se ligar a essa grade particular. Microarrays de DNA permitem que seja estudada a atividade de centenas ou até milhares de genes simultaneamente. O MammaPrint mede o nível de RNA mensageiro de 1.900 diferente genes, e a expressão de 70 genes específicos é medida por seis vezes para que sejam examinados em maior detalhe. Uma vez que o câncer é causado por genes hiperativos, é essencial que se saiba qual gene específico é o causador daquele câncer e isso pode ser determinado por intermédio do uso do 
microarray para comparar a atividade de genes em células saudáveis com a atividade de genes em células tumorais.

O resultado do MammaPrint é muito claro: ou se tem um baixo risco de metástase (bom prognóstico) ou um alto risco (mau prognóstico).

Um fator importante é que o ensaio de MammaPrint requer biópsia de tecido não fixado, o que é mais difícil de ser coletado, mas como resultado cria-se um grande banco de tecidos frescos com perfil clínico e de expressão gênica de cada tumor. Outra desvantagem do teste é que não foi otimizado para pacientes com tumores receptores de estrógeno-positivo tratados com terapia endócrina, uma vez que os genes relacionados com tal terapia nem sempre estão inclusos no MammaPrint ${ }^{16}$.

\section{Oncotype DX}

O Ensaio de Câncer de Mama Oncotype DX é uma forma de teste de diagnóstico que ajuda os pacientes e os médicos a se manterem informados, e torna-os capazes de tomar decisões para um tratamento individualizado. Esse teste é capaz de revelar uma biologia subjacente do tumor que leva a mudanças na decisão do tratamento em até $37 \%$ das vezes.

Trata-se de ensaio multigênico de câncer de mama incorporado nas três maiores diretrizes clínicas: National Comprehensive Cancer Network $\left(\mathrm{NCCN}^{\circledR}\right)$, American Society Clinical Oncology $\left(\mathrm{ASCO}^{\circledR}\right)$ e ST Gallen Consensus. A incorporação do Oncotype DX nessas diretrizes é uma opção que prediz se determinados pacientes se beneficiarão com a quimioterapia.

Visto que nem todas as mulheres respondem da mesma forma à quimioterapia, o Oncotype DX proporciona uma individualizada predição do benefício da quimioterapia e de uma recidiva da doença em até dez anos para influenciar em decisões com tratamentos adjuvantes em mulheres com câncer de mama em estágio precoce.

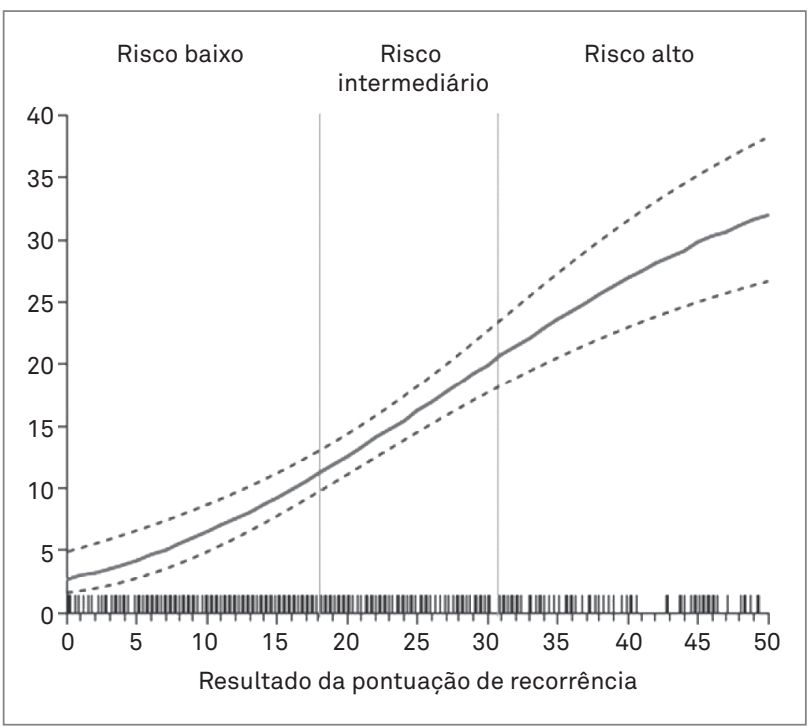

Figura 1: Taxa de recidiva a distância como uma função contínua da pontuação de recorrência, adaptado ${ }^{16}$
O desenvolvimento do ensaio de Oncotype DX foi inspirado no desejo de se quantificar o risco residual de retorno do câncer em pacientes com tumores de mama linfonodo-negativos e receptor de estrógeno-positivo. Os níveis de expressão dos genes são medidos por transcrição reversa multiplex-PCR e um algoritmo matemático usado para calcular a pontuação de recorrência única para cada paciente. Essa pontuação de recorrência foi criada com a intenção de predizer o retorno do tumor independentemente da idade e do tamanho dele, e é preditiva da sobrevida global ${ }^{17}$.

A pontuação de recorrência (Recurrence Score) prediz o benefício da quimioterapia e indica o risco de retorno da doença em dez anos. A pontuação varia de 0 a 100 , no qual as notas mais altas indicam maior probabilidade de recorrência $^{17}$. O uso de RT-PCR permite uma pontuação contínua, ao contrário de um resultado binário (baixo ou alto, somente). Pontuação de recorrência menor que 18 indica baixo risco de desenvolver câncer dez anos após o tratamento. Qualifica o tumor como indolente, sensível à hormonoterapia, e a paciente apresentaria baixo benefício com a quimioterapia. A pontuação com valor de 18 a 31 indica risco intermediário de recorrência do tumor. Já a pontuação de 31 a 100 indica alto risco de recorrência do tumor, classificando-o como agressivo e menos sensível à hormonoterapia (Figura 1). No entanto, essa pontuação também indica um maior benefício adquirido com a quimioterapia.

Foi feito um estudo para comprovar a significância do teste Oncotype DX por meio da análise da pontuação de recorrência. Foi mostrado que a pontuação de recorrência prediz a recorrência distante do tumor para todas as idades e tamanho do tumor. Pacientes com pontuação menor de 18 (baixo risco) tiveram menos frequência de recorrência distante dez anos após o tratamento do que pacientes com pontuação 31 ou mais (alto risco). Além disso, nem todos os pacientes com tumores pequenos foram classificados como baixo risco. A pontuação de recorrência identificou 44 de 109 pacientes que possuíam tumor de $1 \mathrm{~cm}$ como sendo de risco intermediário ou alto. Dessa forma, foi concluído que o uso da pontuação de recorrência como preditor contínuo proporciona uma estimativa precisa do risco de recorrência do tumor em pacientes individuais ${ }^{17}$.

O Oncotype DX é um ensaio baseado em transcrição reversa-PCR de 21 genes e já foi um sucesso na identificação de subconjutos de pacientes com linfonodo-negativos e receptor de estrógeno-positivo. As pacientes tiveram o benefício de, adicionado à quimioterapia, uma terapia adjuvante de antiestrógeno ${ }^{8}$. Além disso, diferentemente do MammaPrint, no qual há necessidade de biópsia de tecido, a plataforma de 21 genes do Oncotype DX tem a vantagem de poder ser empregada em material parafinado, o que ajuda a conservar a amostra até o momento da análise.

Os genes selecionados para compor a plataforma de 21 genes estão envolvidos em importantes processos ligados à 
carcinogênese mamária, como invasão, proliferação e vias relacionadas a receptores hormonais e sinalização de HER2. O Quadro mostra os genes e suas funções.

Esse ensaio já foi clinicamente validado em 13 estudos com mais de 4.000 pacientes ${ }^{17-28}$.

\section{CONCLUSÃO}

O câncer de mama possui uma evolução muito rápida e potencialmente fatal, motivo pelo qual é muito importante seu diagnóstico precoce. O desenvolvimento de novas técnicas de diagnóstico surgiu para melhor atender à paciente e poder inclusive proporcionar um tratamento ideal, de acordo com as características individuais do tumor.

Oncotype DX e MammaPrint são técnicas aprovadas pela Food and Drug Administration (FDA) e atualmente estão em fase de validação para definir mais claramente seus papéis na otimização das terapias para pacientes com câncer de mama linfonodo-negativos. Certamente, na próxima década, teremos o aparecimento de novos marcadores genéticos para o prognóstico cada vez mais precoce do câncer.

Ambos os ensaios apresentam o potencial de identificar pacientes com tumores linfonodo-negativos que não requerem terapia adicional, poupando-as de tratamentos desnecessários e potencialmente tóxicos.

Por meio da análise das vantagens e desvantagens dos ensaios, chega-se à conclusão de que o ensaio OncotypeDX é o mais adequado para o diagnóstico do câncer de mama baseado nas evidências genéticas do tumor da paciente (Quadro 1). Isso se dá por três fatores principais:

1. Utiliza-se uma plataforma de apenas 21 genes (comparado com 70 genes utilizados no MammaPrint).

2. Não é uma técnica invasiva (comparada com a biópsia de tecido no caso do MammaPrint).
Quadro 1: Nomes e funções dos 21 genes utilizados no ensaio OncotypeDx

\begin{tabular}{|lc|}
\hline Gene & Função \\
\hline$A C T B$ & Genes de referência. Normalizam a expressão \\
GAPDH & dos demais genes. \\
GUS & \\
RPLPO & \\
TRFC & \\
KI67 & \\
STK15 & Genes relacionados à proliferação. \\
Survinina & \\
CCNB1 & \\
MYBL2 & \\
MMP11 & \\
CTSL2 & Genes relacionados à invasão. \\
GRB7 & Genes relacionados ao HER-2. \\
HER2 & \\
RE & \\
$P G R$ & \\
$B C L 2$ & Genes relacionados à via estrogênica. \\
SCUBE2 & \\
GSTM1 & \\
$C D 68$ & Outros genes. \\
BAG1 & \\
\hline
\end{tabular}

3. Proporciona uma classificação do tumor em três níveis - risco elevado, intermediário e baixo (comparado com dois níveis do MammaPrint - alto e baixo).

Além disso, enquanto o MammaPrint identifica o tumor apenas se seu nível for no mínimo 30\%, o Oncotype prediz o retorno do tumor independentemente de seu tamanho. Outra diferença é que o MammaPrint não está otimizado para pacientes com tumor receptor de estrógeno positivo, enquanto o Oncotype permite predizer o risco residual de retorno do câncer de mama para estas.

\section{REFERÊNCIAS}

1. Bacchi CE, Prisco F, Carvalho FM, Ojopi EB, Saad ED. Potencial impacto econômico do painel de expressão de 21 genes no tratamento adjuvante do câncer de mama no Brasil. Rev Assoc Med Bras. 2010;56(2):186-91

2. Dowsett M, Dunbier AK. Emerging biomarkers and new understanding of traditional markers in personalized therapy for breast cancer. Clin Cancer Res. 2008:14(24):8019-26.

3. Linhares JJ, Silva ID, Souza NC, Noronha EC, Ferraro O, Baracat FF. Polimorfismo do gene do receptor de progesterona (progins) em mulheres com câncer de mama: estudo caso-controle. Rev Bras Ginecol Obstet. 2005;27(8):473-8.

4. Harvie M, Howell A, Vierkant RA, Kumar N, Cerhan JR, Kelemen LE, et al. Association of gain and loss of weight before and after menopause with risk of postmenopausal breast cancer in the lowa women's health study. Cancer Epidemiol Biomarkers Prev. 2005;14(3):656-61.

5. Eliassen AH, Colditz GA, Rosner B, Willett WC, Hankinson SE. Adult weight change and risk of postmenopausal breast cancer. JAMA. 2006:296(2):193-201.
6. Azevedo G, Mendonça S. Câncer na população feminina brasileira. Rev Saude Publica. 1993:27(1):68-75

7. Koifman RJ, Koifman S, Vieira RJS. Familial aggregation of breast/ ovarian cancer: age of onset along subsequent generations in Brazil. Cad Saude Publica. 1998;14(Suppl. 3):181-5

8. Liu S, Dontu G, Wicha MS. Mammary stem cells, self-renewal pathways, and carcinogenesis. Breast Cancer Res. 2005;7(3):86-95.

9. Dufloth RM, Carvalho S, Heinrich JK, Shinzato YJ, Santos CC, Zeferino LC et al. Análise de mutações nos genes BRCA1 e BRCA2 em pacientes brasileiros com carcinoma de mama e história familiar positiva. São Paulo Med J. 2005:123(4):192-7.

10. Berstein JL, López-Carrillo L, Wang L. The epidemiology of HER-2/neu and P53 in breast cancer. Salud Publica Mex. 1999:41(Suppl 2):S114-23.

11. Corvalán A. Perfiles de expresión génica en decisiones terapéuticas en cáncer de mama. Rev Med Chile. 2007;135(2):257-63.

12. Margarit S. Cáncer hereditario de mama. Rev Chil Radiol. 2008:14(3):135-41. 
13. Shahi PK, Manga GP. Subtipos clínicos y genéticos de câncer de mama: individualización del tratamiento. An Med Interna. 2007;24(12):569-70.

14. Roa JC, Anabalón L, Tapia O, Martínez J, Araya JC, Villaseca M, et al. Promoter methylation profile in breast cancer. Rev Med Chil. 2004;132(9):1069-77.

15. Fonseca FL, Soares HP, Manhani AR, Bendit I, Novaes M, Zatta SM, et al. Peripheral blood c-erbB-2 expression by reverse transcriptasepolymerase chain reaction in breast cancer patients receiving chemotherapy. 2002;3(3):201-5.

16. Olopade OI, Grushko TA, Nanda R, Huo D. Advances in breas cancer: pathways to personalized medicine. Clin Cancer Res. 2008;14(24):7988-99.

17. Paik S, Shak S, Tang G, Kim C, Baker J, Cronin M, et al. A multigene assay to predict recurrence of amoxifen-treated, node-negative breast cancer. N Engl J Med. 2004;351(27):2817-26.

18. Paik S, Tang G, Shak S, Kim C, Baker K, Kim W, et al. Gene expression and benefit of chemotherapy in women with node-negative, estrogen receptor: positive breast cancer. J Clin Oncol. 2006;24(23):3726-34.

19. Dowsett M, Cuzick J, Wale C, Forbes J, Mallon EA, Salter J, et al. Prediction of risk of distant recurrence using the 21 -gene recurrence score in node-negative and node-positive postmenopausal patients with breast cancer treated with anastrozole or tamoxifen: a TransATAC Study. J Clin Oncol. 2010;28(11):1829-34.

20. Albain KS, Barlow WE, Shak S, Hortobagyi GN, Livingston RB, Yeh IT, et al. Prognostic and predictive value of the 21 -gene recurrence score assay in postmenopausal women with node-positive, oestrogenreceptor-positive breast cancer on chemotherapy: a retrospective analysis of a randomised trial. Lancet Oncol. 2010;11(1):55-65.

21. Paik SS, Shak G, Tang C, Kim J, Baker M, Cronin D, et al. Expression of the 21 genes in the Recurrence Score assay and tamoxifen clinica benefit in the NSABP study B-14 of node negative, estrogen receptor positive breast cancer. J Clin Oncol. 2005;23(Suppl 16S):510.
22. Goldstein LJ, Gray R, Badve S, Childs BH, Yoshizawa C, Rowley S, et al. Prognostic utility of the 21-gene assay in hormone receptor-positive operable breast cancer compared with classical clinicopathologic features. J Clin Oncol. 2008;26(25):4063-71.

23. Paik S, Shak S, Tang G, Kim C, Baker J, Cronin M, et al. Multi-gene RTPCR assay for predicting recurrence in node negative breast cancer patients-NSABP studies B-20 and B-14. Breast Cancer Res Treat. 2003; 82:A16.

24. Esteban J, Baker J, Cronin ML, Liu MG, Llamas MG, Walker R, et al. Tumor gene expression and prognosis in breast cancer: multi-gene RT-PCR assay of paraffin-embedded tissue. ASCO Annual Meeting. 2003. Abstract 3416

25. Cobleigh MA, Tabesh B, Bitterman P, Baker J, Baker JCronin M, Liu $\mathrm{ML}$, et al. Tumor gene expression and prognosis in breast cancer patients with 10 or more positive lymph nodes. Clin Cancer Res. 2005;11(24 Pt 1): 8623-31.

26. Esteva FJ, Sahin AA, Cristofanilli M, Coombes K, Lee SJ, Baker J, et al. Prognostic role of a multigene reverse transcriptase-PCR assay in patients with node-negative breast cancer not receiving adjuvant systemic therapy. Clin Cancer Res. 2005;11(9):3315-19.

27. Gianni L, Zambetti M, Clark K, Baker J, Cronin M, Wu J, et al. Gene expression profiles in paraffin-embedded core biopsy tissue predict response to chemotherapy in women with locally advanced breast cancer. J Clin Oncol. 2005;23(29):7265-77.

28. Toi M, Iwata H, Yamanaka T, Masuda N, Ohno S, Nakamura S, et al. Clinical significance of the 21-gene signature (Oncotype DX) in hormone receptor-positive early stage primary breast cancer in the Japanese population. Cancer. 2010;116(13):3112-8.

Endereço para correspondência

Paula Gabriela Casa Cesar - Rua Giovanni Zaia, 115 - Jardim Valdíbia CEP: 09820-090 - São Bernardo do Campo (SP), Brasil -

E-mail:paulagccesar@gmail.com

Conflito de interesse: nada a declarar. 